\title{
Gone to Stamford Bridge? Influence of Foreign Football and Its Digital Coverage on Youths in Abeokuta, Nigeria
}

\author{
Kola Adesina ${ }^{1}$, Adeyemi Obalanlege ${ }^{1}$, Lekan Togunwa ${ }^{2}$ \\ ${ }^{1}$ Department of Mass Communication, Crescent University, Abeokuta, Nigeria \\ ${ }^{2}$ Department of Mass Communication, Babcock University, Ikenne, Nigeria \\ Correspondence: Adeyemi Obalanlege, Crescent University, Abeokuta, Nigeria.
}

E-mail: obalanlege.yemi@crescent-university.edu.ng

Received: March 29, 2017

doi:10.11114/smc.v5i1.2415

\author{
Accepted: May 4, 2017 Online Published: May 11, 2017 \\ URL: https://doi.org/10.11114/smc.v5i1.2415
}

\begin{abstract}
This study investigates the influence of foreign football and its digital coverage among youths in Abeokuta. It examines the values portrayed by internet/satellite technology, the extent to which these values affect Nigerian youths, and the extent to which Nigerian youths' exposure to foreign football through the internet/satellite technology affects their commitment to Nigerian football.

The study employed qualitative method of Focus Group Discussion (FGD), using discussion guide to source data from youth in Abeokuta South and Abeokuta North Local Government Areas.

Among others, the study discovered that major values promoted by internet technology such as technical companionship, global citizenship and technological determinism enhances western values and interests, and have undermined to a very large extent the citizenship values of Nigerian youths. Nigerian youths have practically abandoned their citizenship values such as love and loyalty to the country, patriotism and commitment to national ideas, and have embraced the values promoted by the internet with their passion for foreign football.

The main findings recognises Nigerian youths interest in European football was motivated by good organization, adequate and quality facilities and good football on the field of play; hence Nigerian youths abandoned Nigerian football due to poor management, inadequate and poor facilities and insecurity at match venues, among other factors.

Based on the findings of this study, it is recommended that Nigerian football should be overhauled. There is need for proper funding to fix facilities like quality stadia, provision of security at match venues and ensure proper administration of the games. Youth football should be revived in Nigeria and grassroots football should be re-introduced at primary and secondary school levels to discover raw talents. Adequate arrangement should be made for marketing and sponsorship programmes, including live coverage of football events on the Nigeria television network.
\end{abstract}

Keywords: media, citizenship and football

\section{Introduction}

Marshall McLuhan (1962) predicted the coming of the global village, perhaps few scholars ever thought of the realization of the prediction and the extent of its impact on the world. The Canadian communication scholar had said that major changes in human society would occur with the emergence of Information Communication Technology (Obe, 2005).

Several years after the prediction, the world had never been the same. Ayankojo (2001) explains that Information Technology has brought great and world-wide impacts in areas of business, trade, politics, economy, culture, media and other aspects of life. Another significant impact of Information Technology is the emergence of globalization.

Tiamiyu (2003:35) In Salawu (2006:19) suggests Information and Communication Technologies "are the electronic technologies for creating, acquiring, storing, processing, communicating and using information". The scholar explains that ICTs can be classified along two dimensions: Content-Conduit dimension and Service-Product dimension. Content-Oriented ICTs entails the digital creation and publishing of information content such as database products, electronic books and websites. 
Conduit oriented ICTs provide the channels or media for storing, conveying and transmitting information content (e.g the telephone network). Product-oriented ICTs are physical objects for information processing or transmission equipment such as computers, cellular phones and TV transmitters while service-oriented ICT implies the provision of information services like bulletin boards services, radio broadcast services and online search, through the information infrastructure or systems.

Obe (2005:57) argues, ICTs have become a way of life. ICTs affect how and where man does everything - live, work, play, socialize, entertain, serve, study, rest, heal and protect. These technologies include communication satellite, fax machine, the worldwide web and the internet. Baran (2002:68) in Salawu (2006:20) says the most popular and overwhelming of the ICTs is the internet which is a global network of interconnected computers that communicate freely and share and exchange information. Uimonen (2000:62) in Ayankojo (2001:2009) note the potentials of internet:

\section{If there was a medium that fulfilled our right to express ourselves absolutely, it would have to be the internet. No other medium allows information to flow so freely.... No other medium requires so few resources to reach out to so many.}

Of recent, information and communication technology championed by the internet has changed the face of human existence. The emergence of globalization has altered the course of human society. Izuogu (2006) says globalization and Information Communication Technology are two sides of the same coin. Each of the two concepts cannot be discussed in isolation of the other. Information Communication Technologies are the foundation of the new global information based economy (Erughe and Eehu, 2004).

Until recent time, one aspect of Nigeria's national life that had generated great expression of citizenship and patriotism towards the country, especially by the youth was the game of football.

Nigerians sense of citizenship and commitement to national interest were usually demonstrated by the passion and excitement with which the youths and the young at heart followed the game of soccer played by Nigerian football clubs in the domestic league and other competitions in the country.

Veteran Nigeria Journalist, Fan Nduboke, confirmed the significance of football to Nigeria by saying that:

No other sport has in the history and by history touched the heart and inner soul of Nigeria as football (Nduboke, 1995:8)

In essence, football, the most popular game across the world, was a rallying point for Nigerians and a common ground for demonstrating the 'Nigerianess' in the people. That was between the 1970s, and the end of 1990s when Nigerian domestic league and challenge cup competitions generated great interest and commitment to national ideals. During this period, Nigerian football clubs such as Rangers international, Bendel Insurance, Mighty Jet, Raccah Rovers, Leventis United, Abiola Babes and others enjoyed great patronage and followership. Indeed, these clubs, through football enabled Nigerian youths to express their passion for all that are Nigerian in local football competitions.

However, by the turn of 1990s and the popularity of internet and emergence of globalisation, the interests of Nigerian youths in local football began to wane. The sattelite and cable television- through the internet technology and digitalisation- brought football from other lands to Nigerian homes. Foreign leagues and other competitions such as Italian Seria A, Spanish La Liga, the English Premiership and FA Cup became regular features on television.

To worsen the situation for Nigerian domestic football, lack of proper administrative and marketing arrangements ensured that football competitions among Nigerian clubs are not regularly relayed on television.

Consequently, foreign clubs and players and their exploits attracted the interests of Nigerian youths. Infact, Nigerian youths virtually forgot everything about domestic football while foreign football and players took the centre state in their hearts. Thus, football competitions among Nigerian clubs were no longer appealing to the youths.

It is observed that Nigerian football, the hitherto builder of national pride had almost gone into extinction in the hearts Nigerian youths due to their exposure to foreign football and the overwhelming presence and visibility of the English Premiership, the German Bundesliga, the Italian Seria A, the Spanish La Liga and other football competitions in other parts of the world.

It is in this respect that this study examines the influence of internet on development of citizenship- in relation to Nigerian football- among Nigerian youths in Abeokuta, Ogun State. Several communication scholars and development planners and thinkers are engaged in debates and arguments on the implications of Information Technologies and globalization on various peoples of the world.

Therefore, can we assume that Nigerain youths' exposure to foreign football has undermined their commitment and national spirit as citizens to Nigerian football? 
Hence the following research questions:

1. What are the values being projected by foreign football?

2. Do these values enhance patriotism of Nigerian youths?

\subsection{Role of Football in National Integration}

The game of football, described by Ndubuoke(1995:6) as "man's greatest social invention" "has had a distinguished presence in the history of Nigeria" (Toro, 1995:4). Gbesan (1995) says from a game of relative obscurity, football has developed into a big time sport of big names, big money, big prizes and big fame in Nigeria.

Former Secretary General of Nigerian Football Association, Sanni Ahmed Toro emphasized the significance of football in Nigeria's march to progress by saying that:

If (football) stood proudly tall in the post-colonial era. In times of war and peace, football has been a faithful consort. Therefore, there is so much substance in Nigeria football (Toro, 1995:4)

A sport so magical, so mythical and so euphoric; a common language spoken and understood by every humankind, football remained an avenue for Nigeria "to express its sovereignty and dignity" (Ifeduba, 2011:331). In other words, from the pre-to-post-independence era, "football in Nigeria flaunts rich history of eminent contributions to the development of competitive spirit among youths" (Ndubuoke, 1995:9).

Therefore, as a sport that has contributed to the growth of the country, as a game that has remained as Gbesan(1995:12) puts it, "the youths' pastime, adults recreational outlet, the poor's leisure and the therapy for the rich", it is only appropriate to identify perhaps for today and tomorrow, some of the great achievements of football in the life of Nigeria and its people, perhaps until the advent of the internet that eventually altered the course of the game in Nigeria.

\subsection{Nigerian Football, the Internet and the Dominance of Foreign Leagues}

In Nigeria's history of catching them young and moulding the youths to become whole, football occupies a cherished place. Nigerian football-thirsty youths(through soccer) learn to embrace the spirit of sportmanship : to win honestly and to lose honourably.

From the pre-to post independent era, through the 1970s and the 1980s, football in Nigeria was a great unifying force. The young and old had a meeting point in football. Pre and post match discussions were not based on age, ethnic group or social class of discussants. Either of commendation or condemnation was not given based on the tribal or ethnic background of players. Mostly, it was the Nigerian spirit at work connecting everybody together, with torrents of passions and emotionsdisplayed truly as citizens of Nigeria.

Between 1906 and the 1930s when competitive youth football started at the rudimentary stage, till the end of the 1990s, the game of soccer in Nigeria have had a chequered history. For instance, in Lagos, "which was the heart of the sport then", football loving people formed various clubs and organised friendly matches. The early football clubs included the Chamber Club, Erelu Brothers, the Jollickers, Oluwole Rovers and Muslim Rovers. Through these clubs, "new child prodigies were born in the art of dribbling and making feints". "Young, graceful and talented body swayers were keeping opponents mesmerised and spectators tantalised".

The late 1930s saw the emergence of clubs like L.T.C, Railways, Police and Marine and Carter Corinthians. Outside Lagos, Calabar also served as another centre of footballing actions. Competitive football started in Calabar, when the Berverly Cup competition for Calabar-based teams was launched in 1906. In Warri, Jos and Kano, football competitions among local clubs were also noticeable in the 1930s.

The introduction of the Challenge Cup in 1945 provided for all the clubs in different parts of Nigeria with a national competition and a meeting point. Gbesan(1995:18) says with the challenge cup, football maestros with recognisable individual skill in the game, making superlative contributions to the overall club performance started emerging gradually on the national football scene. In other words, the 1940s and 1950s were the era of clubs such as Lagos Pan Bank, Lagos Dynamos, the Railway and Kano XI. Prominent players of that period included "Thunder", Teslim Balogun, Dan Anyiam and Baba Shittu. The late 1950s and the 1960s belonged to the clubs like the Railway of Lagos, the Mighty Jets of Jos while the post-civil war era of the 1970s saw the introduction of the National League and emergence of Rangers International of Enugu, the IICC Shooting Stars of Ibadan, Raccah Rovers of Kano.

The mid 1970s till the early 1990s was perhaps the most eventful period of Nigerian football. On the local scene, football competitions such as the Challenge Cup and the National League provided Nigeria and Nigerians with much entertainment and packful excitement and passion.

In this period, football served as a major platform of homogenity for Nigerians, and for Nigeria. It was an elixir, the drug to administer on the country to revatilise her moment and period of great national challenges. 
Football clubs like Rangers International of Enugu, IICC of Ibadan, the BCC Lions of Gboko, El-Kanemi Warriors of Maiduguri, Kano Pillars, Stationary Stores of Lagos, Abiola Babes of Abeokuta and Leventis United of Ibadan, created the thrills and excitements that hold Nigerians together and help douse tempers and assuage outburst.

At the international level, Nigeria rose to international prominence, reckoning and prestige with the Green Eagles winning 1980 African Nations Cup, the exploits of the U-17 team, the "Golden Eaglets" that won the FIFA U-17 World Cup, the 1994 African Nations Cup and Nigeria's debut in the world cup in 1994. Indeed, these international exploits repositioned Nigeria on the world football map. Nigeria's achievements on the local and international scenes at this period drew a new wave of interest on its football. Youth football ascended to a greater height. The love for country, devotion to national course, commitment to fatherland, anxiety and excitement laced with patriotism are some of the catchy phrases that could best describe the unifying elements which football generated. Indeed, it was the golden age of Nigerian football.

Since the commencement of the game of soccer in the country till the 1990s, the relationship between Nigeria and football was a story of a nation with a friend indeed. Football remained a true friend and constant ally to Nigeria. Even in the midst of a battle and the rumbles of war, football extended its benevolent hands to the country. Across all seasons, football has demonstrated the capacity to promote peace, love, friendship, togetherness, brotherhood and fellowship among the vast people of Nigeria.

By the end of the 1990s and the turn of 21st century, the fortunes of Nigeria football began to change for the worse. The advent of internet technology and the rise of cable television brought foreign football to the doorstep of Nigerian youths. Foreign leagues and other competitions became a major source of entertainment and fulfilment due to proper organisation and quality play. No doubt, foreign football that could now be watched on multi-channel cable television served as a great challenge to football played in Nigeria.

According to Bosah Chinedu of Education Right Campaign(ERC), the situation for Nigeria football has been worsened by poor organisation and decaying infrastructure. Inadequate funding compounded the crisis with Nigerian football. Bosah Chinedu explains further that "there is lack of security at match venues. Even if you want to be bold watching the matches on the television, the first eyesore is the pitch that is not only galoping but also look like where cattle grass".

Today, Nigerian youths have taken their attention to foreign football. The quality of football watched on the lurch-green stadia, through cable television have created an army of fanatical followership in the Nigerian youths for English Premiership and other major foreign leagues in Europe.

\section{Empirical Review}

There are several empirical works that are related to this study. Two of such empirical works are reviewed.

(a) The political economy of internet: An assessment of the internet's impact on Nigeria and its development.

The study was published in 2009 by Diri Tuotamuno. It examines the application of the new media technologies to development process. The paper observed that information revolution offers Nigeria a dramatic opportunity to break out from decades of stagnation and decline. In this respect, the paper suggests that Nigeria should explore the internet technology to enhance its anti-corruption efforts, promote participatory governance, improve public administration, stimulate local economies and improve journalism.

In other words, Nigeria and other African countries should seize the opportunities of internet to further their progress.

The paper concluded that despite these prospects, developing countries such as Nigeria are likely to be even more marginalised and economically stagnant in future because they consume the technologies, rather than create them.

(b) European football club newspapers in Nigeria: Gratifications or Media imperialism? This study traces the emergence of European football club newspapers in Nigeria and examines the uses and gratifications of their contents by football lovers, especially the youths in the country. It was authored by Emmanuel Ifeduba and published in 2011.

The study identified some of the European Clubs' newspapers established in Nigeria and their editorial focus. The newspapers are presented below:

\section{$\mathrm{S} / \mathbf{N} \quad$ Newspaper name}

1. Manchester United for Life

\section{Editorial Focus}

For those who love good

\section{football}

2. Barca Newsreel

The official Camp-Nou Voice 
3. The Real Madrid Echo

in Nigeria for the true Barca fans

\begin{tabular}{|c|c|c|}
\hline & & Madridista \\
\hline 4. & Barcelona Focus & $\begin{array}{l}\text { The Nigeria Weekly Voice for the } \\
\text { Blaugrana }\end{array}$ \\
\hline 5. & Midweek Arsenal Focus & Field of Truth \\
\hline 6. & The Blues & $\begin{array}{l}\text { The Round Leather game } \\
\text { Weekly }\end{array}$ \\
\hline 7. & Weekend Arsenal Focus & Field of Truth \\
\hline 8. & Gunners Weekly & For the True Gunners in Nigeria \\
\hline 9. & True Blues & $\begin{array}{l}\text { Nigeria's number } 1 \text { official } \\
\text { Chelsea FC Weekly Tabloid. }\end{array}$ \\
\hline
\end{tabular}

With the aid of content analysis, the study examined the contents of the nine titles. It was discovered that the birth of these newspapers indicates an increasing number of Nigerian football fans shifting their support to foreign football clubs.

The study also reported that the new media owners are simply responding to the forces of demand and supply with the central objective of meeting an unmet local need for good, professionally organised football. The implication as the study observed is that news of foreign leagues is published by Nigerian citizens to draw away readers from local league, a development which is bound to affect negatively the nation's sporting culture.

The paper recommends that the fans will continue to patronise these newspapers so long as their needs for good football is not satisfied by any of the local newspapers and the country itself.

\section{Methodology}

This study was designed to investigate the influence of football and its digital coverage on youths in Abeokuta. In order to achieve this objective, qualitative focus group discussion (FGD) was used. According to Awoniyi et al (2011), qualitative research entails collecting, analysing and interpreting data by observing what people do and say.

\section{Study Population}

The study setting is Abeokuta, Ogun State. Youths that are residents of the town (ages between 18-30 years old) constitute the respondents for this study. The rationale for their consideration is because the youths constitute a major percentage of internet users who are likely to be highly exposed to the internet values. In the same vein, the youths constitute the greatest followership of football both at home and international levels.

\section{Sampling Procedure and Size}

In order to choose a sample that will be representative of youths in Abeokuta, stratified sampling technique was used. Stratified sampling is the approach used to get adequate representation of a sub-sample by segmenting them based on exclusive characteristics. To select subjects for this study therefore, youths in Abeokuta were delineated on the basis of the two local government areas of Abeokuta Township: Abeokuta South and North.

Using purposeful and accidental sampling, 10 youths were picked to represent Abeokuta South local government area, covering Onikolobo - Ibara axis of the town. This area is highly populated by youths who are in Higher education, with access to internet and digital television. Also, the Ibara area is the centre of digital and internet business, including internet cafes and football viewing centres mostly visited by the youths in Abeokuta.

From the Abeokuta North local government area, 10 youths were picked from Oke-Sokori/Totoro/Lafenwa axis. This areas are also populated by youths who are also active internet surfers and followers of football.

\section{Focus group Discussion}

The discussion guide was relied on for the study's primary data. The disucussion guide was divided into three sections. The first section comprises of twelve(12) questions for discussion on Nigerian football in order to elicit information from the respondents on what their knowledge of Nigerian football is; their level of interest in Nigerian football in relation to the Nigerian Premier League and other competitions and their impression of and suggestions of the state of nigerian football.

The second section also has twelve(12) questions and focuses on the respondents' use of internet technology and their 
exposure to foreign football via the cable television. Issues discussed include their knowledge of foreign football, especially european leagues such as English Premier League, and other major Leagues and their star players, level of interest in those foreign leagues, and other competitions and their impression of the state of foreign football especially European football.

The third section with six(6) questions focuses on comparison between Nigreian football and European football. Discussants were encouraged to discuss the state of Nigerian football as compared with European football. Suggestions were encouraged on how to improve the state of Nigerian football.

Eventually, the discussion guide was administered on each of the two groups that constituted respondents for the study. The 10 youths from Onikolobo/Ibara axis from Abeokuta South Local Government, and another 10 youths from Oke-Sokori/Totoro/Lafenwa axis that made up sample of youths from Abeokuta North. All the members of the two groups participated actively in the discussions.

\section{Data Analysis and Discussion of Findings}

Here the data collected through the discussion guide are presented, analysed and discussed. Findings are discussed in relation to raised research questions.

This section is divided into two. The first presents the data obtained through the discussion guide in relation to its three major areas: discussion on Nigerian football, discussion on internet/satellite television facilitated exposure to foreign football and discussion on comparison between the state of Nigerian and Foreign football. The second section focuses on discussion of findings with the aim of answering the research questions of the study.

\section{(A) Discussion on Nigerian football}

This discussion centres on knowledge of Nigerian football, level of interest in Nigerian football, and impression of the state of Nigerian football.

\subsection{Respondents Knowledge of Nigerian Football}

Most of the respondents from the two groups showed near-total lack of knowledge of Nigerian football. From the dscussions, it was obvious that they were not aware of developments in Nigerian football, especially the football league.

For instance, 19 of the 20 youths could not mention the coach of the Gateway Football Club, Abeokuta neither could they mention the club's star players. In the same vein, 18 of the 20 youths claimed not to have a favourite club or player in the Nigerian League.

Findings show that they did not seek to know about developments in Nigerian football. The little they know was obtained when once in a while they listened to information from Nigeria media. Very few of them have a bit of information about Nigerian football competitions because their relations plays for one of the clubs in Nigeria League or because the clubs are from their states of origin.

For instance, only two of the 20 youths claimed to have favourite club and player in the Nigerian League. One of them said his brother plays for 3SC of Ibadan, hence the club and his brother are his favourite, while the other person claimed to be from Kwara State, hence the club is his favourite.

\subsection{Level of Interest in Nigerian Football}

From the discussion, it was discovered that:

i. All 20 respondents said they are not interested in the Nigerian football.

ii. For example, none could identify the first three teams on the top of the Nigerian Premier League.

iii. None could mention the coaches of any of the clubs in Nigeria.

iv. Nore of the respondents could recollect that it was Eyimba Fottball Club that won the 2014 FA Cup in Nigeria.

v. None could recollect that it was Kano Pillars that won the 2014 Nigerian Premier League title.

\subsection{Respondents Impression on the State of Nigerian Football}

The discussions show that:

i. $\quad$ All the respondents have bad impression of Nigerian football

ii. They expressed their dissappointment with the management of Nigerian Premier League.

iii. They mentioned corruption, poor facilities, improper funding, insecurity as some of the problems with Nigerian football. 
iv. They complained that Nigerian football over the years has not been giving them what they want-quality football, good management and quality infrastructure.

\subsection{Discussion on the Use of Internet/Satellite Television and Exposure to European Football}

This section centres on the respondents use of the internet and values of the technology, knowledge of the European football, level of interest in foreign football leagues, and impression of the state of foreign football.

\subsection{Respondents Use of Internet and Value of the Technology}

The discussions with the group shows that:

1. All the 20 youths are internet surfers.

2. They surf internet everyday, everytime.

3. They surf the internet for information and to relate with friends.

4. They claimed internet is like a companion and their best friend.

5. Ability to connect with various people in all parts of the world exposes them to various ideologies and cultures.

6. They are more of global citizens operating from Nigeria.

7. The internet is their major information and entertainment source, and social relations and interaction platform.

8. Through the sattelite technology, they have access to cable TV to watch football on multi-channel platforms.

\subsection{Respondents Knowledge on Foreign/European Football}

Findings from the discussion shows that:

1. Virtually all of them are quite knowledgeable of European football, especially the current sensation-English Premiership.

2. Their knowledge of European football, especially the English Premiership ranges from performances of the various clubs, their positions on Premiership table, star players and their worths, the capacities of the coaches and the player that is likely to be bought or sold by different clubs.

3. For instance, they expressed their knowledge of European football by saying that the 2014/2015 English Premier was won by Chelsea FC and that the three teams that topped the League are Chelsea FC, Manchester City and Arsenal FC.

4. Similarly, 16 out of the 20 youths said immediately that currently the most expensive player in European football is Gareth Bale of Real Madrid, bought for 89 million pounds from Tottenham Hotspurs. They also expressed their deep knowledge of European football by saying that the most expensive player in the English Premiership is Raheem Sterlin of Manchester City who was bought for 49 million pounds from :Liverpool FC.

\subsection{Respondents Interest in Foreign/European Football}

The discussions indicated that:

1. Most of the respondents are highly interested in foreign football, especially English Premiership..

2. The interests cover different football clubs in the English Premiership and Spanish football.

3. Each of the respondents has his favourite club and players.

4. Their interests in these clubs have attained fanatical level with emotions, passion and excitement always exhibited in favour of the team(s).

5. The interest were predicated on the fact that European football gives them what they want- quality football and well managed games.

6. As a fan of any of the team, every respondent is ready to defend his team to high heavens.

7. For instance, everyone of them have his favourite European team . their favourite teams include FC Barcelona, Chelsea FC, Manchester United FC, Manchester City FC, Arsenal FC, FC Real Madrid, Liverpool FC, Bayern Munich FC.

8. Also, every of the youths claimed to have atleast a star player in the European Leagues. Some of their star players are: Lionel Messi of Barcelona, Eden Hazard and Ivanovic of Chelsea FC, Wayne Rooney and Robin Van Persie of Manchester United, Yaya Toure, Edin Dzeko and Sergio Aguero of Manchester City. 
9. Respondents interest in European football is also predicated on the roles of betting programmes for football contests. There are football betting programmes such as Naija bet, Merry bet and 1960 bet. Football fans can stake their money for any clubs in the world. Winners are given to those that won the bet.

10. Nigeria football league is not usually considered for the betting game.

11. To further demonstrate their interest, they know virtually the stadia of the major clubs in Europe such as:
i. Emirate stadium - Arsenal FC
ii. Stamford Bridge - Chelsea FC
iii. Anfield - Liverpool FC
iv. Etihad Stadium - Manchester City
v. Real Madrid - Santiago Bennerbeu
vi. Old Trafford - Manchester United FC

\subsection{Impression on the State of European Football}

All respondents have positive impression of the European Football;

1. They believed in the effective management of European football.

2. They are satisfied with the quality of offerings from European football.

3. They will continue to passionately support European Clubs due to the entertainment, satisfaction and quality football they derive from the clubs' matches.

\subsection{Comparism between Nigerian and European Football}

From the discussions, respondents are of the opinion that:

1. European football cannot be compared with Nigerian football in all forms.

2. European football is far ahead in terms of organisation, funding, quality of facilities, players' welfare, marketing programmes of football played and management of the game.

3. An European Footballer may not be naturally skillful than his Nigerian counterpart but his mastery of the game is enhanced by welfare package and stimulating 'playing' enviroment.

4. Nigeria football can still reach level of European football if the trend is reversed. That is if Nigeria football is overhauled and managed in the right direction.

5. Their total commitment still stays with European football until Nigerian football is improved.

\subsection{Section Two}

The discussion of this section aims at providing answers to research questions raised in this study.

\subsection{Research Question One}

What are the values being projected by foreign football

This question intends to identify the values that are derivable from the potentials of exposure to foreign football through satellite television/internet streaming.

The Focus Group discussions, with the two youth groups sampled from Abeokuta would be relied on. Findings from the discussions indicate the following internet values as identifid by the youths:

1. The Value of Companionship: The internet is a major companion for the youths. They surf the net regularly. Thus, it stands as their ally and friend.

2. Global Citizenship: Another value of the internet is that of global citizenship. As regular internet users and satellite television viewers, people operate on a global platform which internet represents. It appears their interactions with people from other parts of the world takes them away from their immediate enviroment to the world stage.

3. Unipolar World: Another internet value is unipolarism. Through the internet, the world is being defined as a single entity where everything western is being structured as the ideal.

4. The Value of Technological Determinism: The internet portrays technology as the determinants of most human activities conducted by the youths.

5. Immediate and quick solution to human problems 
6. High level mobility

7.12 Research Question Two

Do these values enhance patriotism of Nigerian youths?

This question intends to establish the extent to which values being projected by foreign/European football are enhancing or undermining patriotism of Nigerian youths.

The Focus Group discussions with the youths indicates that Nigeria citizenship values are being undermined in the Nigerian youths.

Nigerian citizenship ideals such as: love for the country, interest in national affairs, sense of loyalty and patriotism and others are being challenged and almost overwhelmed by internet values of global citizenship and unipolarism which promote western ideals.

Obviously, the youths reactions to questions in sections one, two and three of the Discussion Guide indicate that their citizenship values have been undermined by their passion for European football and their distate for Nigerian football.

The fact is that the internet promotes western orientation in the youth to negate all that are standards of Nigerian citizenship. The Nigerian youths, with their exposure through the internet to western values, coupled with the fact that the internet serves as a good companion, are shifting attention from national ideals to western ideals. This means Nigerian citizenship values are gradually being dominated by the internet promoted western ideals. Therefore, one can conclude to a very large extent, internet values and exposure to European football have undermined the citizenship values of Nigerian youths.

This study further intend to establish the extent to which Nigerian youths' commitment to Nigerian football has been affected by their exposure to European football facilitated by the internet.

Findings from the discussions with the youths established firmly that attention has almost totally shifted from Nigerian football to European football. Infact, it was confirmed through their responses to questions in Sections 2 of the Discussion Guide that the major attractions of the European football include good organisation, quality display of football artistry, easy access to the matches through cable television and attractive and well laid football pitches as portrayed on screen.

A Nigerian Communication scholar confirmed this position by saying that:

The coming of DSTV, Eurosport and other sports channels through cable and satellite technology began gradually in the 1990s to shift fans' interest from local league to European leagues. (Ifeduba, 2011:332)

The Nigerian youths followership and commitment to European football has been very massive to the extent that viewing centres have emergd to take care of those that cannot pay for cable television in their homes to watch the matches.

The growing fanatism for European football has been quite intense to the extent that after the UEFA Champions' League match between Chelsea FC and Manchester United on May 21, 2008, seven youths lost their lives while several others were badly wounded due to clashes and celebration.

Findings also indicated that once they are at the various Viewing Centres, Nigerian youths would have emotionally left their physical enviroment for the stadia where matches are played. In other words, their presence in Nigeria was only physical, emotionally, they are part of the spectators at the Emirate, Old Trafford, Allianz Arena, Stamford Bridge or any other stadia where matches are played.

However, it was not only good organisation of European football that took their attention away from Nigerian football. Nigeria football is crisis ridden, corruption, poor infrastructure, bad management and absence of good marketing programmes that could bring the matches to our television screen are some of the factors undermining Nigerian football.

Bosah Chinedu of the Education Rights Campaign also capsures this position by saying that:

Pathetically, organisation and facilities are now missing and that is why we have one of the worst leagues in the world.

Remarkably, Nigerians' passion and interest in European football is not limited to the youths. One recalls that few years back, the then Govenor of Lagos State, Raji Fashola invited the Captain of Manchester United, Rio Ferdinand to Lagos State, perhaps to express he was part of the craze for European football.

Recently, media reports indicated that Aliko Dangote, a Nigerian businessman and one of the richest Africa desires to buy and take over Arsenal FC on English Premiership. It appears Nigerian football will remain in the doldrum for a long 
time if members of the ruling elites, those that suppose to revive it, are joining the craze for European football.

In short, as it stands, Nigeria football has lost the vibrancy, passion and attention of its youths to European football. Great and comprehensive efforts would be required by all to stakeholders to reverse the trend.

Therefore, to a very large extent, Nigerian youths' exposure to European football had adversely affected their commitment and patriotic zeal for Nigerian football.

\section{Conclusion}

Based on the findings of this study, Nigerian youths have abandoned local football in the country in favour of European football. Their passion, dedication and commitment are for foreign football clubs.

Again, Nigerian youths are regular internet surfers and have embraced the values of the technology like technology companionship, technology determinism, and global citizenship. European football enjoys great followership among Nigerian youths, and this is linked to strategic football management and high level funding the game enjoys in Europe. These are identified as source of European football attraction to Nigerian youths. Unlike, leadership deficit; Poor management; corruption, and poor facilities presently available to Nigerian youths.

This study has been able to establish that European football obtained the interest of Nigerian youths majorly because Nigerian football is in disarray. It has also been able to establish that impressive managment of European football and quality football on quality pitches are part of the attractions that got the interest of Nigerian youths. Furthermore, the study has been able to identify internet values that are undermining Nigerian citizenship values in our male youths. Similarly, poor management of Nigerian football drew the youths to find solace in European football.

Therefore, further studies can be conducted to locate the place of marketing and sponsorship in the revival of Nigerian football. Studies can also be conducted on the role of football in the revival of citizen.

The study recommends, Nigerian football needs to be overhauled in order to attract more funding which would lead to provision of modern facilities like quality stadia, provision of security at match venues and ensure proper administration of the game in the country.

Youth football should be revived in Nigeria. Grassroots football should be re-introduced at primary and secondary school levels to discover raw talents for future greatness, while adequate arrangement should be made for marketing and sponsorship programmes, facilitating league matches being relayed on television to cultivate the interest of the youths and all Nigerians.

The government should create policies to moderate youths' exposure to internet materials. If left to the mercy of the internet, Nigerian youths would be overwhelmed by those values that would continously undermine nigerian citizenship values. The government should discharge its obligations to cultivate demonstration of citizenship values from Nigerians, while private organisation and individuals should be encouraged to establish football clubs as business.

\section{References}

Aina, S. (2003). Anatomy of Communications. Abeokuta: Julian Publishers.

Anaeto, G. (2008). Localism in Communication for Development in a Globalized World' in Mojaye, E; Oyewo, O; M'Bayo, R. and Sobowale I. (eds) Globalization and Development Communication in Africa. Ibadan: Ibadan University Press.

Anaeto, G., Onabajo, O., \& Osifeso, J. (2008). Models and Theories of Communication. Maryland: African Renaissance Books Inc.

Awoniyi, S., Aderanti, R., \& Tayo, A. (2011). Introduction To Research Methods. Ibadan: Ababa Press Ltd.

Ayankojo, K. (2001). Expanding the Frontiers of Public Relations through the Internet' in Oso L, and Ayankojo K. (eds) Basic Public Relations, Abeokuta: Gbenga Gbesan Associates.

Babalola, B. (2011). Rudiments of Democracy. Abeokuta: PRIMUS Prints \& Communications.

Baran, S. (2004). Introduction To Mass Communication. New York: McGraw-Hill.

Baran, S., \& Davis, D. (2003). Mass Communication Theory: Foundations, Ferments and Future. Belmont: Thomson Wadworth.

Bittner, J. (1989). Mass Communication: An Introduction. New Jersey: Prentice Hall.

Bosah Chiendu 'Nigerian Youth And European Football'. www.gamji.com/article.

Dower, N. (2003). An Introduction To Global Citizenship. Edinburgh University Press.

Folarin, B. (1998). Theories of Mass Communication: An Introductory Text. Ibadan: Stirling-Horden. 
Golding, P., \& Harris, P. (1997). Beyond Cultural Imperialism (Globalization, Communication and the New International Order. London: SAGE Publications Ltd.

Hamm, \& Russell, S. (2005). Cultural Imperialism. Toronto: Broadview Press.

Ifeduba, E. (2001). European Football in Nigeria: Gratifications or Media Imperialism, Journal of India, 1(9).

Imhnopi, D., \& Oladeinde, M. (2009). Utilization of Internet Services In Nigeria: Opportunities and Threats.

Izwogu, K. (2006). Information Technology in Traditional Society: In Search of Relevance' in Nwosu, I. and Soola, O. (eds) Communication in Global, ICTs \& Ecosystem Perspectives. Enugu: Precision Publishers Ltd.

Keghku, T. (2013). An Evaluation of the Positive and Negative Impacts of ICTs on the Nigerian Youths', Public Relations Journal, 9(1).

Littlejohn, S., \& Foss, K. (2005). Theories of Human Communication. Belmont: Thomson Wadsworth.

Marshall, M. (1962). The Gutenberg Galaxy: The making of typographic man. Toronto: University of Toronto Press.

Ndubuoke, F. (1995). Whistle Blast' in Gbesan, G. (ed) Nigeria At The World Cup: The Play and the Pity. Abeokuta: The GGA.

Ndubuoke, F. (1995). Whistle Blast' in Gbesan, G. (ed) Nigeria At The World Cup: The Play and the Pity. Abeokuta: The GGA.

Nwodu, L. (2006). ICTs, Globalization and Domination of African Values: A Development Communication Perspective' in Nwosu, I. and Soola, O. (eds) Communication in Global, ICTs \& Ecosystem Perspectives. Enugu: Precision Publishers Ltd.

Obe, J. (2005). Repositioning PR Practice in Nigeria in the face of New Information and Communication Technologies" in Odetoyinbo, A; Alagbe, B. and Dokunmu, F. (eds) PR Media and Methods. (Image Maker PR Journal) Abeokuta: Ogun NIPR.

Oso, L. (2006). The Internet, Public Sphere and Democracy in Nigeria' in Nwosu, I. and Soola, O. (eds) Communication in Global, ICTs \& Ecosystem Perspectives. Enugu: Precision Publishers Ltd.

Salawu, A. (2006). ICTs and Development: A Paradigm Somersault' in Nwosu, I. and Soola, O. (eds) Communication in Global, ICTs \& Ecosystem Perspectives. Enugu: Precision Publishers Ltd.

Salawu, A. (2008). A Development Communication: The Preliminaries' in Mojaye, E; Oyewo, O; M'Bayo, R. and Sobowale I (eds) Globalization and Development Communication in Africa. Ibadan: Ibadan University Press.

Tejumaiye, J. (2008). The Yoruba 'Omoluabi' in the Age of Globalization: Issues and Challenges for Development Communication' in Mojaye, E; Oyewo, O; M'Bayo, R. and Sobowale I. (eds) Globalization and Development Communication in Africa. Ibadan: Ibadan University Press.

Thussu, D. (2000). International Communication-Continuity And Change. New York: Arnold.

Toro, S. (1995). Flag Up' in in Gbesan, G. (ed) Nigeria At The World Cup: The Play and the Pity. Abeokuta: The GGA.

Tuotamino, D. (2009). The Political Economy of the Internet: An Assessment of the Internet's Impact on Nigeria and its Development' in Oso, L; Odunlami, D. and Ajibola, T. (eds). Media, Governance And Development (Book of Proceedings) Ago-Iwoye: OOU.

Wilson, D. (2006). Informational Technology in Traditional Society: In Search of Relevance' in Nwosu, I. and Soola, O. (eds) Communication in Global, ICTs \& Ecosystem Perspectives. Enugu: Precision Publishers Ltd.

Wilson, D. (2008). Development Communication and Globalization' in Mojaye, E; Oyewo, O; M'Bayo, R. and Sobowale I. (eds) Globalization and Development Communication in Africa. Ibadan: Ibadan University Press.

Wilson, J., \& Wilson, S. (2001). Mass Media, Mass Culture. New York: McGraw-Hill.

\section{Copyrights}

Copyright for this article is retained by the author(s), with first publication rights granted to the journal.

This is an open-access article distributed under the terms and conditions of the Creative Commons Attribution license which permits unrestricted use, distribution, and reproduction in any medium, provided the original work is properly cited. 